\title{
Neurso endocrinology
}

No. 1

Original Papers

1 Projections to the Preoptic Area from the Paraventricular Nucleus, Arcuate Nucleus and the Bed Nucleus of the Stria Terminalis Are Unlikely to Be Involved in Stress-Induced Suppression of GnRH Secretion in Sheep

Rivalland, E.T.A.; Tilbrook, A.J.; Turner, A.I.; Iqbal, J.; Pompolo, S.; Clarke, I.J. (Melbourne, Vic.)

14 Effects of $p$-Nonylphenol and 4-tert-Octylphenol on the Anterior Pituitary Functions in Adult Ovariectomized Rats Furuta, M.; Funabashi, T.; Kawaguchi, M.; Nakamura, T.J.; Mitsushima, D. (Yokohama); Kimura, F. (Yokohama/Odawara)

21 Regulation of Proopiomelanocortin Gene Transcription during Single and Repeated Immobilization Stress Noguchi, T.; Makino, S.; Maruyama, H.; Hashimoto, K. (Nankoku)

31 Regulation of 5'-Promoter Activity of the Rat Growth Hormone and Growth Hormone-Releasing Hormone Receptor Genes in the MtT/S and MtT/E Cells

Nogami, H. (Tsukuba); Hiraoka, Y. (Tokyo); Inoue, K. (Saitama); Aiso, S. (Tokyo); Hisano, S. (Tsukuba)

42 Expression of Tyrosine Kinase Receptors in Malignant Midgut Carcinoid Tumors

Welin, S.; Fjällskog, M.L.; Saras, J.; Eriksson, B.; Janson, E.T. (Uppsala)

49 Neuropeptide Urocortin and Its Receptors Are Expressed in Rat Kupffer Cells

Charalampopoulos, I.; Androulidaki, A.; Minas, V. (Heraklion); Chatzaki, E. (Alexandroupolis); Tsatsanis, C.; Notas, G.; Xidakis, C.; Kolios, G.; Kouroumalis, E.; Margioris, A.N.; Gravanis, A. (Heraklion)

58 Dopaminergic Mechanisms Involved in Prolactin Release after Mifepristone and Naloxone Treatment during Late Pregnancy in the Rat

Soaje, M.; Valdez, S. (Mendoza); Bregonzio, C. (Córdoba); Penissi, A.; Deis, R.P. (Mendoza)

\section{No. 2}

Historical Vignette

69 Evolution of the Diffuse Neuroendocrine System - Clear Cells and Cloudy Origins

Modlin, I.M.; Champaneria, M.C.; Bornschein, J.; Kidd, M.

(New Haven, Conn.)

Appetite and Energy Balance

83 Effect of Fasting on Cocaine-Amphetamine-Regulated Transcript, Neuropeptide Y, and Leptin Receptor Expression in the Non-Human Primate Hypothalamus

Van Vugt, D.A.; Lujan, M.E.; Froats, M.; Krzemien, A. (Kingston); Couceyro, P.R. (North Chicago, Ill.); Reid, R.L. (Kingston)
94 Hemorrhage Results in Hepatic Insulin-Sensitizing SubstanceDependent Insulin Resistance Mediated by Somatostatin in Rats

Seredycz, L.I.; Lautt, W.W. (Winnipeg)

103 Effect of Leptin Administration on Ovulation in Food-Restricted Rhesus Monkeys

Lujan, M.E.; Krzemien, A.A.; Reid, R.L.; Van Vugt, D.A. (Kingston)

GHRH, Somatostatin, Growth Hormone and IGF

115 Testosterone Inhibition of Growth Hormone Release Stimulated by a Growth Hormone Secretagogue. Studies in the Rat and Dog

Rigamonti, A.E.; Cella, S.G.; Giordani, C.; Bonomo, S.M.; Giunta, M. (Milan); Sartorio, A. (Milan/Piancavallo); Müller, E.E. (Milan)

GnRH, Gonadotropins, Gonadal Steroids and Reproduction

123 Estrogen Differentially Modulates the Cannabinoid-Induced Presynaptic Inhibition of Amino Acid Neurotransmission in Proopiomelanocortin Neurons of the Arcuate Nucleus Nguyen, Q.H.; Wagner, E.J. (Pomona, Calif.)

Comparative Neuroendocrinology

138 Evidence for the Presence of Molecules Related to the Neuropeptide CGRP in Two Cephalopods, Sepia officinalis and Nautilus macromphalus: Comparison with Its Target Organ Distribution

Lafont, A.-G.; Dufour, S.; Fouchereau-Peron, M. (Concarneau/Paris)

\section{No. 3}

ENETS Consensus Guidelines for the Management of Patients with Digestive Neuroendocrine Tumors

Part 1 - Stomach, Duodenum and Pancreas

Guest Editors: De Herder, W. (Rotterdam); O'Toole, D. (Clichy); Rindi, G. (Parma); Wiedenmann, B. (Berlin)

Introduction

155 Consensus Guidelines for the Management of Patients with Digestive Neuroendocrine Tumors: Why Such Guidelines and How We Went about It

Rindi, G. (Parma); de Herder, W.W. (Rotterdam); O’Toole, D. (Clichy); Wiedenmann, B. (Berlin)

ENETS Guidelines

158 Well-Differentiated Gastric Tumors/Carcinomas

Ruszniewski, P. (Clichy); Delle Fave, G. (Rome); Cadiot, G. (Paris); Komminoth, P. (Baden); Chung, D. (Boston, Mass.); Kos-Kudla, B. (Zabrze); Kianmanesh, R. (Colombes); Hochhauser, D. (London); Arnold, R. (Marburg); Ahlman, H. (Gothenburg); Pauwels, S. (Brussels); Kwekkeboom, D.J. (Rotterdam); Rindi, G. (Parma) and all other Frascati Consensus Conference participants

\section{KARGER}

Fax +4161306 1234 E-Mail karger@karger.ch www.karger.com

\section{2006 S. Karger AG, Basel}

Access to full text and tables of contents, including tentative ones for forthcoming issues: www.karger.com/nen_issues 
165 Well-Differentiated Duodenal Tumor/Carcinoma (Excluding Gastrinomas)

Jensen, R.T. (Bethesda, Md.); Rindi, G. (Parma); Arnold, R. (Marburg); Lopes, J.M. (Porto); Brandi, M.L. (Firenze); Bechstein, W.O. (Frankfurt); Christ, E. (Bern); Taal, B.G. (Amsterdam); Knigge, U. (Copenhagen); Ahlman, H. (Gothenburg); Kwekkeboom, D.J. (Rotterdam); O’Toole, D. (Clichy) and all other Frascati Consensus Conference participants

173 Gastrinoma (Duodenal and Pancreatic)

Jensen, R.T. (Bethesda, Md.); Niederle, B. (Vienna); Mitry, E. (Boulogne); Ramage, J.K. (Hampshire); Steinmüller, T. (Berlin); Lewington, V. (Sutton) Scarpa, A. (Verona); Sundin, A. (Uppsala); Perren, A. (Zurich); Gross, D. (Jerusalem); O’Connor, J.M. (Buenos Aires); Pauwels, S. (Brussels); Klöppel, G. (Kiel) and all other Frascati Consensus Conference participants

183 Well-Differentiated Pancreatic Tumor/Carcinoma: Insulinoma de Herder, W.W. (Rotterdam,); Niederle, B. (Vienna); Scoazec, J.-Y. (Lyon); Pauwels, S. (Brussels); Klöppel, G. (Kiel); Falconi, M. (Verona); Kwekkeboom, D.J. (Rotterdam); Öberg, K.; Eriksson, B. (Uppsala); Wiedenmann, B. (Berlin); Rindi, G. (Parma); O’Toole, D. (Clichy); Ferone, D. (Genoa) and all other Frascati Consensus Conference participants

189 Rare Functioning Pancreatic Endocrine Tumors O’Toole, D. (Clichy); Salazar, R. (Barcelona); Falconi, M. (Verona); Kaltsas, G. (Athens); Couvelard, A. (Clichy); de Herder, W.W. (Rotterdam); Hyrdel, R. (Martin); Nikou, G. (Athens); Krenning, E. (Rotterdam); Vullierme, M.-P. (Clichy); Caplin, M. (London); Jensen, R. (Bethesda, Md.); Eriksson, B. (Uppsala) and all other Frascati Consensus Conference participants

196 Well-Differentiated Pancreatic Nonfunctioning

Tumors/Carcinoma

Falconi, M. (Verona); Plöckinger, U. (Berlin); Kwekkeboom, D.J.

(Rotterdam); Manfredi, R. (Verona); Körner, M. (Bern); Kvols, L.

(Tampa, Fla.); Pape, U.F.; Ricke, J. (Berlin); Goretzki, P.E. (Neuss); Wildi, S.

(Zurich); Steinmüller, T. (Berlin); Öberg, K. (Uppsala); Scoazec, J.-Y. (Lyon) and all other Frascati Consensus Conference participants

212 Poorly Differentiated Carcinomas of the Foregut (Gastric, Duodenal and Pancreatic)

Nilsson, O. (Gothenburg); Van Cutsem, E. (Leuven); Delle Fave, G. (Rome); Yao, J.C. (Houston, Tex.); Pavel, M.E. (Erlangen); McNicol, A.M. (Glasgow); Sevilla Garcia, M.I. (Malaga); Knapp, W.H. (Hannover); Keleştimur, F. (Kayseri); Sauvanet, A. (Clichy); Pauwels, S. (Brussels); Kwekkeboom, D.J. (Rotterdam); Caplin, M. (London) and all other Frascati Consensus

Conference participants

216 Author Index

\section{No. 4}

At the Cutting Edge

217 A Novel Apoptosis Gene Identified in the Pituitary Gland Farrell, W.E. (Stoke on Trent)

Minireview

222 Central Nervous System Circuitry Involved in the Hyperinsulinism Syndrome

Lechin, F.; van der Dijs, B. (Caracas)

Appetite and Energy Balance

235 Effects of Estradiol on Glycemic and CNS Neuronal Activational Responses to Recurrent Insulin-Induced Hypoglycemia in the Ovariectomized Female Rat Nedungadi, T.P.; Goleman, W.L.; Paranjape, S.A.; Kale, A.Y.; Briski, K.P (Monroe, La.)
Sixth International Congress of Neuroendocrinology June 19-22, 2006, Pittsburgh, Penn., USA

Symposia Session: Neurosteroids and Neuroprotection

Guest Editors: Blaustein, J.D. (Amherst, Mass.); Melcangi, R.C. (Milan)

Neurosteroids and Neuroprotection

244 Neuroactive Steroids in Depression and Anxiety Disorders: Clinical Studies

Eser, D.; Schüle, C.; Baghai, T.C. (Munich); Romeo, E. (Rome); Rupprecht, R. (Munich)

255 Local Neurosteroid Production in the Hippocampus: Influence on Synaptic Plasticity of Memory

Mukai, H.; Tsurugizawa, T.; Ogiue-Ikeda, M.; Murakami, G.; Hojo, Y.;

Ishii, H.; Kimoto, T.; Kawato, S. (Tokyo)

264 Stress in Pregnancy Activates Neurosteroid Production in the Fetal Brain

Hirst, J.J. (Callaghan); Yawno, T. (Clayton); Nguyen, P. (Prahran); Walker, D.W. (Clayton)

275 Cross-Talk between IGF-I and Estradiol in the Brain: Focus on Neuroprotection

Garcia-Segura, L.M.; Sanz, A. (Madrid); Mendez, P. (Madrid/Geneva)

280 ENETS Newsletter

No. 5

GnRH, Gonadotropins, Gonadal Steroids and Reproduction

285 Gonadotropin-Releasing Hormone Functionally Antagonizes Testosterone Activation of the Human Androgen Receptor in Prostate Cells through Focal Adhesion Complexes Involving Hic-5

Maudsley, S.; Davidson, L.; Pawson, A.J.; Freestone, S.H.; López de Maturana, R.; Thomson, A.A.; Millar, R.P. (Edinburgh)

301 Molecular Genetic Analysis of Normosmic Hypogonadotropic Hypogonadism in a Turkish Population: Identification and Detailed Functional Characterization of a Novel Mutation in the Gonadotropin-Releasing Hormone Receptor Gene Topaloglu, A.K. (Adana); Lu, Z.-L. (Edinburgh); Farooqi, I.S. (Cambridge); Mungan, N.O.; Yuksel, B. (Adana); O’Rahilly, S. (Cambridge); Millar, R.P. (Edinburgh)

CRF, Adrenocorticotropin, Adrenal Steroids and Stress

309 Suppression of Adrenocorticotrophic Hormone Secretion by Simultaneous Antagonism of Vasopressin $\mathbf{1 b}$ and CRH-1 Receptors on Three Different Stress Models Ramos, A.T.; Troncone, L.R.P.; Tufik, S. (São Paulo)

317 Cloning, Distribution, and Colocalization of MNAR/PELP1 with Glucocorticoid Receptors in Primate and Nonprimate Brain Khan, M.M.; Hadman, M.; De Sevilla, L.M.; Mahesh, V.B.; Buccafusco, J. Hill, W.D.; Brann, D.W. (Augusta Ga.)

Neuroendocrinology and Thermoregulation

330 The Role of the Selective Serotonin Reuptake Inhibitor Fluoxetine in Temperature Regulation in Ovariectomized Rat Models

Maswood, N.; Cosmi, S.; Alfinito, P.D. (Collegeville, Pa.); Leventhal, L. (Princeton, N.J.); Deecher, D.C. (Collegeville, Pa.)

Posterior Pituitary Hormones

339 Chronic Hypernatremia Increases the Expression of Vasopressin and Voltage-Gated $\mathrm{Na}^{+}$Channels in the Rat Choroid Plexus

Szmydynger-Chodobska, J.; Chung, I.; Chodobski, A. (Providence, R.I.) 
Clinical Neuroendocrinology and Neuroendocrine Tumors

346 TNF- $\alpha$ Promoter Single Nucleotide Polymorphisms in Gastroenteropancreatic Neuroendocrine Tumors Berković, M.; Čačev, T.; Zjačić-Rotkvić, V.; Kapitanović, S. (Zagreb)

\section{No. 6}

GnRH, Gonadotropins, Gonodal Steroids and Reproduction

353 Orexin A Induces GnRH Gene Expression and Secretion from GT1-7 Hypothalamic GnRH Neurons

Sasson, R.; Dearth, R.K.; White, R.S.; Chappell, P.E.; Mellon, P.L. (La Jolla, Calif.)

364 Regulation of the Hypothalamic Melanin-Concentrating Hormone Neurons by Sex Steroids in the Goldfish: Possible Role in the Modulation of Luteinizing Hormone Secretion Cerdá-Reverter, J.M. (Edmonton/Ribera de Cabanes); Canosa, L.F. (Edmonton/Chascomus); Peter, R.E. (Edmonton/Bamfield)

378 Orchidectomy Increases $\beta$-Adrenoceptor Activation-Mediated Neuronal Nitric Oxide and Noradrenaline Release in Rat Mesenteric Artery

Blanco-Rivero, J.; Aras-López, R.; Del Campo, L.; Sagredo, A.; Balfagón, G.; Ferrer, M. (Madrid)
Posterior Pituitary Hormones

386 Co-Expression of Tyrosine Hydroxylase and GTP Cyclohydrolase I in Arginine Vasopressin-Synthesizing Neurons of the Human Supraoptic Nucleus Demonstrated by Laser Microdissection and Real-Time PCR

Kontostavlaki, D.P. (Athens/Amsterdam); Panayotacopoulou, M.T. (Athens); Sluijs, J.A.; Unmehopa, U.A.; Huitinga, I.; Hol, E.M.; Swaab, D.F. (Amsterdam)

396 Vasopressin-Containing Neurons of the Hypothalamic Parvocellular Paraventricular Nucleus of the Jerboa: Plasticity Related to Immobilization Stress

Barakat, Y. (Fez); Pape, J.R. (Talence); Boutahricht, M.; El Ouezzani, S.; Alaoui, A. (Fez); Chaigniau, M. (Talence); Barakat, L. (Fez); Tramu, G. (Talence); Mâgoul, R. (Fez)

Hormone Actions in the Brain

405 In the Ventral Tegmental Area, Progestins' Membrane-Mediated Actions for Lordosis of Hamsters and Rats Involve Protein Kinase A

Petralia, S.M.; Walf, A.A.; Frye, C.A. (Albany, N.Y.)

415 Author Index Vol. 84, 2006

417 Subject Index Vol. 84, 2006
S. Karger

Medical and Scientific Publishers Basel $\cdot$ Freiburg $\cdot$ Paris $\cdot$ London New York $\cdot$ Bangalore $\cdot$ Bangkok Singapore $\cdot$ Tokyo $\bullet$ Sydney
Disclaimer

The statements, options and data contained in this publication are solely those of the individual authors and contributors and not of the publisher and the editor(s). The appearance of advertisements in the journal is not a warranty, endorsement, or approval of the products or services advertised or of their effectiveness, quality or safety. The publisher and the editor(s) disclaim responsibility for any injury to persons or property resulting from any ideas, methods, instructions or products referred to in the content or advertisements.

Drug Dosage

The authors and the publisher have exerted every effort to ensure that drug selection and dosage set forth in this text are in accord with current recommendations and practice at the time of publication. However, in view of ongoing research, changes in government regulations, and the constant flow of information relating to drug therapy and drug reactions, the reader is urged to check the package insert for each drug for any change in indications and dosage and for added warnings and precautions. This is particularly important when the recommended agent is a new and/or infrequently employed drug.
All rights reserved.

No part of this publication may be translated into other languages, reproduced or utilized in any form or by any means, electronic or mechanical, including photocopying, recording, microcopying, or by any information storage and retrieval system, without permission in writing from the publisher or, in the case of photocopying, direct payment of a specified fee to the Copyright Clearance Center (see 'General Information').

(C) Copyright 2006 by S. Karger AG,

P.O. Box, CH-4009 Basel (Switzerland)

Printed in Switzerland on acid-free paper by

Reinhardt Druck, Basel 